Honour for Mr. D. MoK. Malcolm

The Royal African Society's bronze medal 'for dedicated service to Africa' has been awarded to Mr. Daniel McKinnon Malcolm (Natal). The citation says that Mr. Malcolm, now 72, has spent a life-time in the service of the Zulu people. He is one of the greatest authorities on the Zulu language and Zulu literature. He was in the Public Service for 43 years, and was ultimately Chief Inspector of Native Education. On his retirement in 1946 he was appointed to take charge of the Department of Zulu in the University of Natal. Mr. Malcolm has written a Zulu manual and has published a very large number of authoritative articles on Zulu in various periodicals. $\mathrm{He}$ is a member of the Mission Council of the Church of Scotland and a member of the Council of the South African Institute of Race Relations. As Chief Inspector of Native Education, he was greatly beloved and exercised much influence on the education of the Zulus.

\title{
Republication of Rare Books on African Languages
}

Ar the international meeting of linguists held in London under the auspices of CCTA (see p. 187 above) it was decided to draw up a list of those African grammars and dictionaries and other linguistic works of permanent value that are now out of print but are still continually needed and sought after. Works from this list will be reprinted or reproduced photographically as funds become available.

Dr. Guy Atkins was asked to compile a list of such works and, in order to make the list as complete as possible, is seeking the help and advice of Africanists in all parts of the world. $\mathrm{He}$ will be grateful for any suggestions regarding this list of books, and also for the names and addresses of any other persons (including language committees, university and government departments, publishers, booksellers) who might be able to assist him in his task.

Recommendations of works to be included in the list should specify the following points :

I. Name of the African territory concerned.

2. Name of the author.

3. Title of the book.

4. Number of volumes and pages.

5. Publisher.

6. Place and date of publication.

7. Price (if known).

8. A note on the scope and value of the book.

9. The place where a copy can be found.

Io. Details of any previous attempt to get the book republished.

Replies should be sent to: Dr. Guy Atkins, School of Oriental and African Studies, University of London, W.C. $I$.

\section{Activités au Congo Belge de l'Institut de Sociologie Solvay}

Nous avons fait brève mention des développements récents en matière de sciences sociales au Congo Belge dans Africa, octobre 1956, p. 41 I; Monsieur le Professeur Doucy, de l'Université Libre de Bruxelles, a eu la bonté de nous fournir les détails qui suivent au sujet du programme des activités au Congo Belge de l'Institut de Sociologie Solvay.

L'Institut de Sociologie Solvay de l'Université Libre de Bruxelles a créé à Élisabethville un Centre d'études sociologiques auquel sont attachés des ethnologues qualifiés et spécialistes de recherches sociales qui y ont été détachés de Bruxelles. Diverses études scientifiques sont 